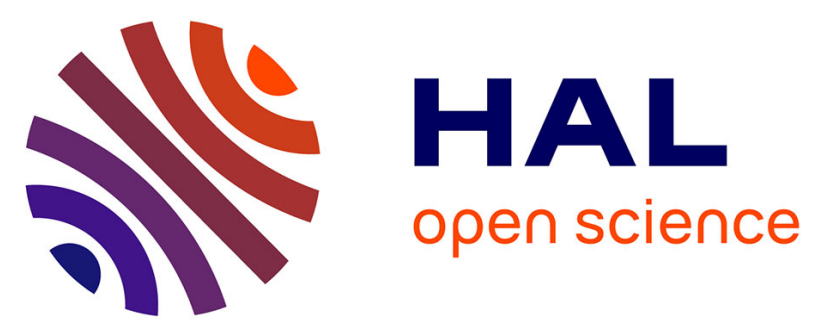

\title{
N-Methylpyrrolidin-2-one hydrotribromide (MPHT) a mild reagent for selective bromination of carbonyl compounds: synthesis of substituted 2-bromo-1-naphtols
}

Alain Bekaert, Olivier Provot, Olimihamina Rasolojaona, Mouad Alami, Jean-Daniel Brion

\section{To cite this version:}

Alain Bekaert, Olivier Provot, Olimihamina Rasolojaona, Mouad Alami, Jean-Daniel Brion. NMethylpyrrolidin-2-one hydrotribromide (MPHT) a mild reagent for selective bromination of carbonyl compounds: synthesis of substituted 2-bromo-1-naphtols. Tetrahedron Letters, 2005, 46 (24), pp.4187-4191. 10.1016/j.tetlet.2005.04.049 . hal-02394630

\section{HAL Id: hal-02394630 \\ https://hal.science/hal-02394630}

Submitted on 4 Dec 2019

HAL is a multi-disciplinary open access archive for the deposit and dissemination of scientific research documents, whether they are published or not. The documents may come from teaching and research institutions in France or abroad, or from public or private research centers.
L'archive ouverte pluridisciplinaire HAL, est destinée au dépôt et à la diffusion de documents scientifiques de niveau recherche, publiés ou non, émanant des établissements d'enseignement et de recherche français ou étrangers, des laboratoires publics ou privés. 
archives-ouvertes

\section{N-Methylpyrrolidin-2-one hydrotribromide (MPHT) a mild reagent for selective bromination of carbonyl compounds: synthesis of substituted 2-bromo-1-naphtols}

Alain Bekaert, Olivier Provot, Olimihamina Rasolojaona, Mouad Alami, Jean-Daniel Brion

\section{To cite this version:}

Alain Bekaert, Olivier Provot, Olimihamina Rasolojaona, Mouad Alami, Jean-Daniel Brion. NMethylpyrrolidin-2-one hydrotribromide (MPHT) a mild reagent for selective bromination of carbonyl compounds: synthesis of substituted 2-bromo-1-naphtols. Tetrahedron Letters, Elsevier, 2005, 46 (24), pp.4187-4191. 10.1016/j.tetlet.2005.04.049 . hal-02394630

\section{HAL Id: hal-02394630 \\ https://hal.archives-ouvertes.fr/hal-02394630}

Submitted on 4 Dec 2019

HAL is a multi-disciplinary open access archive for the deposit and dissemination of scientific research documents, whether they are published or not. The documents may come from teaching and research institutions in France or abroad, or from public or private research centers.
L'archive ouverte pluridisciplinaire HAL, est destinée au dépôt et à la diffusion de documents scientifiques de niveau recherche, publiés ou non, émanant des établissements d'enseignement et de recherche français ou étrangers, des laboratoires publics ou privés. 


\title{
N-Methylpyrrolidin-2-one hydrotribromide (MPHT) a mild reagent for selective bromination of carbonyl compounds: synthesis of substituted 2-bromo-1-naphtols
}

\author{
Alain Bekaert, Olivier Provot ${ }^{*}$, Olimihamina Rasolojaona, Mouâd Alami* and Jean-Daniel \\ Brion \\ Laboratoire de Chimie Thérapeutique, BioCIS-CNRS (UMR 8076), Université Paris-Sud, Faculté de Pharmacie, rue J.B. Clément 92296 \\ Châtenay-Malabry Cedex, France
}

\begin{abstract}
The reaction of the $N$-methylpyrrolidin-2-one hydrotribromide complex (MPHT) with substituted-1-tetralones has been investigated. This safety reagent proved to be successful for selective $\alpha$ - $\alpha$-dibromination of tetralones. Moreover, under base free conditions, several 2-bromo-1-naphtols were obtained from tetralones in a "one pot" sequence in good to excellent yields.
\end{abstract}

Bromination of carbonyl compounds is an important transformation, as the resulting $\alpha$-brominated products are versatile intermediates in organic synthesis. ${ }^{1}$ Although the $\alpha$-bromination of ketones is now well documented, ${ }^{2}$ the $\alpha, \alpha$-dibromination reaction has received little attention. The most commonly used reagent for this transformation requires elemental bromine, ${ }^{3}$ which have several environmental drawbacks. The handling of liquid bromine, due to its hazardous nature, is troublesome and special equipment and care are needed for the transfer of these materials in large scale. In order to overcome these problems, alternative methods for preparing $\alpha, \alpha$ dibromoketones have been developed such as $\mathrm{HBr}-\mathrm{H}_{2} \mathrm{O}_{2},{ }^{4}$ 1,3-dibromo-5,5-dimethylhydantoin, ${ }^{5}$ polymer supported brominating reagents, ${ }^{6} \mathrm{KBr}-\mathrm{KBrO}_{3}$-Dowex, ${ }^{7}$ or dioxanedibromide-silica gel under microwave irradiation. ${ }^{8}$ While these reactions are suitable methods, in the case of robust substrates, it would be useful to have alternative sources of bromine that offer advantages of safety, selectivity, mild reaction conditions and stability.

As a part of our program aimed at the development of new and selective reagents for the preparation of $\alpha$-halogenated carbonyl compounds, ${ }^{9}$ we had previously improved the synthesis of a crystalline bromine complex $\mathrm{N}$ Methylpyrrolidin-2-one hydrotribromide (MPHT, $\left.[\mathrm{NMP}]_{2} \mathrm{HBr}_{3}\right) \mathbf{1}$ (Figure 1) and determined its structure by * Keywords : halogenation; MPHT; 1-tetralones; 2-bromo-1-naphtols. * Corresponding authors. E-mail : olivier.provot@ cep.u-psud.fr ; mouad.alami@cep.u-psud.fr means of single-crystal X-ray diffraction methods. ${ }^{10}$ This complex is insensitive to moisture and showed a remarkable stability at room temperature. Even though no decrease in free bromine titer could be detected when exposed to air for several months, nothing is known about its reactivity.

An important aspect of our ongoing research on the synthetic utility of $\mathbf{1}$ as soft acting brominating reagent in organic synthesis led us to investigate its reactivity with carbonyl compounds. Herein, we report the results of this study and the use of complex MPHT 1 for the selective preparation of $\alpha, \alpha$-dibrominated tetralones $\mathbf{3}$ suitable substrates for the construction of substituted 2-bromo-1naphtols 4.

The synthesis of MPHT complex $\mathbf{1}$ was achieved readily in $87 \%$ yield $^{11}$ under a slighly modified Daniels' procedure ${ }^{12}$ using a $\mathrm{HBr}$ solution (30\% in acetic acid) instead of gaseous $\mathrm{HBr}$.

The reactivity of the MPHT complex 1 was evaluated with several 1-tetralones in order to prepare the $\alpha, \alpha$ dibrominated compounds. First, we investigated this reaction in $\mathrm{CH}_{3} \mathrm{CN}$, solvent that we have previously found to be efficent in $\alpha$-iodination of ketones. ${ }^{9}$ Thus, reaction of tetralone $\mathbf{2 a}$ with the MPHT complex $\mathbf{1}$ ( 2 equiv) at room temperature gave the desired $\alpha, \alpha$-dibrominated tetralone $\mathbf{3 a}$ 
in very low yield (10\%). The effect of temperature was then examinated and we found that heating the reaction at $50^{\circ} \mathrm{C}$, provided the expected tetralone $3 \mathbf{a}$ in $79 \%$ yield after stirring for $12 \mathrm{~h}$. However, when the reaction was run at $80^{\circ} \mathrm{C}$, we were pleased to observe complete conversion of the starting material $\mathbf{2 a}$ within $30 \mathrm{~min}$ and $\mathbf{3 a}$ was isolated in $90 \%$ yield (Table 1, entry 1). Of the several solvents tested, MeCN gave the highest yield of $\alpha, \alpha$-dibrominated tetralone 3a. The other solvents including $\mathrm{CH}_{2} \mathrm{Cl}_{2}$, toluene, dioxane and DMF gave unsatisfactory yields of $\mathbf{3 a}$.

The results of the dibromination reaction of various substituted tetralones $\mathbf{2}$ with the MPHT complex $\mathbf{1}$ in $\mathrm{CH}_{3} \mathrm{CN}$ are summarized in Table 1. Under these optimized conditions, ${ }^{13}$ good yields of dibrominated tetralones $\mathbf{3}$ were obtained except when the reaction is carried out from tetralone 2f. In this case, $39 \%$ of tetralone $3 \mathbf{f}$ were isolated together with $20 \%$ of 2-bromo-1-naphtol $\mathbf{4 f}$.

Since 2-bromo-1-naphtol derivatives are interesting reagents for metal catalyzed coupling reaction ${ }^{15}$ and particulary for the synthesis of heterocyclic products ${ }^{16}$, it would be useful to transform the dibrominated tetralones 3 into their corresponding 2-bromo-1-naphtols 4 . To this end, tetralones 3 were reacted for 30 minutes at room temperature with an excess of $\mathrm{Et}_{3} \mathrm{~N}$ (10 equiv) in $\mathrm{CHCl}_{3}$, and the expected 2-bromo-1-naphtols 4 were obtained in good to high yields (Table 1).

In order to simplify this transformation from the point of view of the synthetic chemist, our aim was also to obtain $\alpha$ bromonaphtol derivatives 4 in a one-pot procedure without isolation of the intermediate $\alpha$ - $\alpha$-dibrominated products $\mathbf{3}$. Thus, we investigated the reaction of tetralone $\mathbf{2 a}$ with MPHT complex ( 2 equiv) in acetonitrile in the presence of an excess of $\mathrm{Et}_{3} \mathrm{~N}(3 \mathrm{~mL} / 1 \mathrm{mmol}$ of tetralone $2 \mathbf{a})$ at $80^{\circ} \mathrm{C}$ for $18 \mathrm{~h}$. Under these conditions, the dibrominationdehydrobromination process does not occurred and starting material was recovered unchanged, probably owing to an undesirable reaction between $\mathrm{NEt}_{3}$ and electrophilic MPHT. However, by adding $\mathrm{Et}_{3} \mathrm{~N}$ in the media after completion of the dibromination step (disapperance of tetralone $\mathbf{2 a}$ after $30 \mathrm{~min}$ as juged by TLC) we were pleased to observe that, the expected 2-bromo-1-naphtol $4 \mathbf{a}$ was isolated in $76 \%$ isolated yield after stirring for $30 \mathrm{~min}$ at room temperature.

To examine if the presence of $\mathrm{Et}_{3} \mathrm{~N}$ is necessary for the dehydrobromination step, we performed the reaction of tetralone 2a with the MPHT complex 1 (2 equiv) in boiling $\mathrm{CH}_{3} \mathrm{CN}$ for a prolongated reaction time (18h). In these base free conditions, we observed a fully dehydrobromination of the intermediate $\alpha, \alpha$-dibrominated tetralone $3 \mathbf{a}$ to give the expected 2-bromo-1-naphtol $\mathbf{4 a}$ in a one step sequence in $78 \%$ yield. These base free conditions have been applied successfully to the preparation $\alpha$-bromonaphtol derivatives 4 from tetralones 2 (Scheme 1).
Moreover, we were pleased to observe that tetralone $\mathbf{2 f}$ has been transformed successfully (95\% vs 60\%) into its corresponding bromonaphtol $\mathbf{4 f}$ under microwave irradiation.

For a complete understanding of this dehydrobromination reaction, we have stirred the $\alpha$ - $\alpha$-dibrominated tetralone $\mathbf{3 a}$ in $\mathrm{CH}_{3} \mathrm{CN}$ for 18 hours at $80^{\circ} \mathrm{C}$. The result of this experiment showed a partial thermal dehydrobromination of 3a producing $\mathbf{4 a}$ in only $25 \%$ yield. However, if the experiment is carried out in $\mathrm{CH}_{3} \mathrm{CN}$ in the presence of $\mathrm{N}$ Methyl-2-pyrrolidin-2-one (4 equiv), the expected 2bromo-1-naphtol 4a was obtained in an excellent isolated yield $(90 \%)$. This result clearly indicated that in the case of dibromination-dehydrobromination process, the MPHT complex acted first, as a safe and selective brominating agent and subsequently, the NMP liberated in the media promoted the thermal dehydrobromination step, when reactions were performed for a prolongated reaction time $\left(80^{\circ} \mathrm{C}\right)$. Under these thermal and base free conditions (2 equiv of 1), it should be noted that no products resulting from bromination of activated aromatic ring could be detected.

Interestingly, we showed if an excess of MPHT was used, selective electrophilic aromatic bromination on the aryl ring occurred. Thus, reaction of 7-methoxytetralone $\mathbf{2 d}$ with the MPHT complex 1 ( 3 equiv) in acetonitrile at $80^{\circ} \mathrm{C}$ for a night, provided selectively 2,6-dibromo-7-methoxy-1naphtol $\mathbf{4 g}$ in $83 \%$ yield. The MPHT complex acted this time at first, as a $\alpha$ - $\alpha$-dibrominating agent, then assisted the dehydrobromination step and finally permitted the bromination of the intermediary naphtol derivative $4 \mathbf{d}$ (Figure 2).

Finally, it is noteworthy that the use of a stoichiometric amount of the MPHT complex 1, exclusively monobromination of tetralones $\mathbf{2}$ occurred. Thus, in $\mathrm{CH}_{2} \mathrm{Cl}_{2}, \alpha$-bromination of $\mathbf{2 a}$ with the MPHT complex 1 (1 equiv) provided the corresponding $\alpha$-bromoketone at room temperature in $80 \%$ yield, comparable with those obtained to bromination with elemental bromine (e.g. $72 \rightarrow 99 \%)^{18}$.

In summary, we have examined the synthetic potential of the MPHT complex $\mathbf{1}$ in the bromination reactions of various tetralones. This complex, which could be prepared in large amounts (multi-moles scale) and could be stored several months at room temperature, permitted the selective mono and/or dibromination of various substituted tetralones. Moreover, under base-free conditions, in boiling $\mathrm{CH}_{3} \mathrm{CN}$, the $\mathrm{N}$-Methylpyrrolidin-2-one liberated in the media assisted and completed the thermal dehydrobromination of intermediary dibrominated tetralones to lead in a one pot sequence to the expected 2bromo-1-naphtol derivatives. 
The ease of MPHT use in selective bromination(s) and subsequent dehydrobromination(s) together with its crystalline state, make it very attractive in organic chemistry. Other selective bromination reactions with aliphatic ketones and electrophilic aromatic bromination are now in progress in our Laboratory.

\section{Acknowledgments}

The CNRS is gratefully acknowledged for financial support of this research. We wish to thank also la Ligue Contre le Cancer for a doctoral fellowship to O.R.

\section{References and notes}

1 (a) Bolton, R. In Bromine Compounds: Chemistry and Applications, Price, D.; Iddon, B.; Wakefield, B. J., Elsevier, Amsterdam, 1988, p 151. (b) De Kimpe, N.; Verhé, R. In The chemistry of $\alpha$-haloketones $\alpha$-haloaldehydes and $\alpha$-haloimines, Patai, S.; Rappoport, Z., Wiley, 1988.

2 For recent advances on $\alpha$-bromination of carbonyl compounds, see: (a) Tanemura, K.; Suzuki, T.; Nishida, Y.; Satsumabayashi, K.; Horaguchi, T. Chem. Commun. 2004, 470-471. (b) Lee, J. C.; Park, J. Y.; Yoon, S. Y.; Bae, Y. H.; Lee, S. J. Tetrahedron Lett. 2004, 45, 191-193. (c) Lee, J. C.; Bae, Y. H.; Chang, S.-K. Bull. Korean Chem. Soc. 2003, 24, 407-408. (d) Choi, H. Y.; Chi, D. Y. Org. Lett. 2003, 5, 411-413.

3 (a) House, H. O.; McDaniel, W. C. J. Org. Chem. 1977, 42, $2155-$ 2160. (b) Lambert, C.; Nöll, G.; Schmälzlin, E.; Meerholz, K; Bräuchle, C. Chem. Eur. J. 1998, 4, 2129-2135. (c) Hatzigrigoriou, E.; Spyroudis, S.; Vargolis, A. Liebigs Ann. Chem. 1989, 167-170. (d) Plieninger, H.; Völkl, A. Chem. Ber. 1976, 109, 2121-2125.

4 Tillu, V. H.; Shinde, P. D.; Bedekar, A. V.; Wakharkar, R. D. Synth Commun. 2003, 33, 1399-1403.

5 Spitulnik, M. J. Synthesis 1985, 299-300.

6 Sket, B.; Zupan, M. Synth. Commun. 1989, 19, 2481-2487.

7 Kosmrlj, J.; Kocevar, M.; Polanc, S. Synth. Commun. 1996, 26, $3583-$ 3592 .

8 Satya, P.; Gupta, V.; Gupta, R.; Loupy, A. Tetrahedron Lett. 2003, 44, 439-442.

9 Bekaert, A.; Barberan, O.; Gervais, M.; Brion, J.-D. Tetrahedron Lett. 2000, 41, 2903-2905.

10 Bekaert, A.; Barberan, O.; Kaloun, E.B.; Danan, A.; Brion, J.-D.; Lemoine, P.; Viossat, B. Z. Kristallogr. NCS 2001, 216, 1-2.

11 Preparation of MPHT: To a 2 L round bottomed flask, cooled in an ice bath and equipped with a dropping funnel and a condenser, were added, successively, $200 \mathrm{~mL}$ of $\mathrm{MeOH}$ and $250 \mathrm{~mL}$ (one drop per second) of $\mathrm{HBr}(30 \%$ in acetic acid) while maintening the internal temperature between $10^{\circ} \mathrm{C}$ and $15^{\circ} \mathrm{C}$. Elemental bromine, $60 \mathrm{~mL}$, was then added by the dropping funnel ( 2 drops per second) and the solution was stirred for 10 minutes. Then, N-Methylpyrrolidin-2-one, $250 \mathrm{~mL}$, was added by the dropping funnel ( 2 drops per second). The mixture was stirred for 1 hour at $10^{\circ} \mathrm{C}$ and orange crystals were collected, washed with $\mathrm{Et}_{2} \mathrm{O}(4 \times 50 \mathrm{~mL})$ and dried under vacuum to give $440 \mathrm{~g}$ of MPHT 1 as orange crystals (yield $=87 \%$ ). mp. 122$124^{\circ} \mathrm{C} .{ }^{1} \mathrm{H}$ NMR $\left(\mathrm{CDCl}_{3}, 200 \mathrm{MHz}\right) \delta 2.25(\mathrm{~m}, 4 \mathrm{H}), 2.90(\mathrm{t}, 4 \mathrm{H}, \mathrm{J}=8$ $\mathrm{Hz}), 3.00(\mathrm{~s}, 6 \mathrm{H}), 3.75(\mathrm{t}, 4 \mathrm{H}, \mathrm{J}=7.2 \mathrm{~Hz}), 14.6(\mathrm{bs}, 1 \mathrm{H}),{ }^{13} \mathrm{C} \mathrm{NMR}$ $\left(\mathrm{CDCl}_{3}, 200 \mathrm{MHz}\right) \delta 18.3,31.4,33.3,52.8,178.3$. IR $\mathrm{cm}^{-1}: 3339$, $1640,1420,1228$.

12 Daniels, W. E.; Chaddix, M. E.; Glickman, S. A. J. Org. Chem. 1963, 28, 573-574.

13 General procedure for the $\alpha, \alpha$-dibromination of tetralones with MPHT 1: In a round bottomed flask, a solution of tetralone 2 (1 mmol) in $\mathrm{CH}_{3} \mathrm{CN}(10 \mathrm{~mL})$ was stirred in an oil bath at $80^{\circ} \mathrm{C}$ and then MPHT ( $2 \mathrm{mmol}$ ) was added dropwise (each drop was added only after the previous drop had completely decolorized). The mixture was then stirred for 30 additional minutes at this temperature. The reaction mixture was cooled to $20^{\circ} \mathrm{C}$ and treated with a saturated $\mathrm{Na}_{2} \mathrm{~S}_{2} \mathrm{O}_{3}$ solution. The organic layer was washed with $\mathrm{HCl} 10 \%(3 \times 10 \mathrm{~mL})$ and dried over $\mathrm{MgSO}_{4}$. Removal of the solvent yielded a crude product, which was purified by silica gel flash chromatography to afford $\mathbf{3}$ (see Table 1 for yields).

14 All new compounds were characterized by ${ }^{1} \mathrm{H},{ }^{13} \mathrm{C}$ NMR and IR.

3c: $\mathrm{mp} .85^{\circ} \mathrm{C}$. ${ }^{1} \mathrm{H} \mathrm{NMR}\left(\mathrm{CDCl}_{3}, 200 \mathrm{MHz}\right) \delta 2.90(\mathrm{~s}, 4 \mathrm{H}), 3.70(\mathrm{~s}$, $3 \mathrm{H}), 6.65(\mathrm{~d}, 1 \mathrm{H}, \mathrm{J}=2.1 \mathrm{~Hz}), 6.85(\mathrm{dd}, 1 \mathrm{H}, \mathrm{J}=8.3,2.1 \mathrm{~Hz}), 8.05$ (d, $1 \mathrm{H}, \mathrm{J}=8.3 \mathrm{~Hz}) \cdot{ }^{13} \mathrm{C} \mathrm{NMR}\left(\mathrm{CDCl}_{3}, 200 \mathrm{MHz}\right) \delta 29.5,46.0,55.6,67.8$, 112.3, 114.5, 120.2, 132.4, 144.7, 164.4, 183.0. IR cm ${ }^{-1}: 1684,1596$, 1494 .

3d: $\quad m p . \quad 88-90{ }^{\circ} \mathrm{C} . \quad{ }^{1} \mathrm{H} \quad \mathrm{NMR} \quad\left(\mathrm{CDCl}_{3}, \quad 200 \quad \mathrm{MHz}\right)$

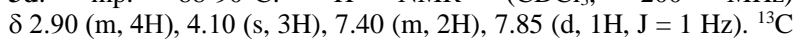
$\mathrm{NMR}\left(\mathrm{CDCl}_{3}, 200 \mathrm{MHz}\right) . \delta 28.4,46.0,55.5,67.3,111.5,123.0$, 128.0, 129.8, 134.6, 158.8, 184.1. IR cm ${ }^{-1}: 1498,1283$

3e: mp. $83^{\circ} \mathrm{C} .{ }^{1} \mathrm{H}$ NMR $\left(\mathrm{CDCl}_{3}, 200 \mathrm{MHz}\right) \delta 2.95(\mathrm{~m}, 4 \mathrm{H}), 3.80(\mathrm{~s}$, $3 \mathrm{H}), 3.82(\mathrm{~s}, 3 \mathrm{H}), 3.90,(\mathrm{~s}, 3 \mathrm{H}), 7.40(\mathrm{~s}, 1 \mathrm{H}) .{ }^{13} \mathrm{C} \mathrm{NMR}\left(\mathrm{CDCl}_{3}, 200\right.$ $\mathrm{MHz}) . \delta$ 23.1, 45.6, 56.0, 60.6, 60.8, 67.2, 107.4, 122.2, 129.9, 145.6, 149.8, 152.8, 185.1. IR cm ${ }^{-1}: 1691,1589,1485$.

3f: ${ }^{1} \mathrm{H} \mathrm{NMR}\left(\mathrm{CDCl}_{3}, 200 \mathrm{MHz}\right) \delta 3.30(\mathrm{~m}, 4 \mathrm{H}), 7.50(\mathrm{t}, 1 \mathrm{H}, \mathrm{J}=8$ $\mathrm{Hz}), 8.00(\mathrm{dd}, 1 \mathrm{H}, \mathrm{J}=8 \mathrm{~Hz}, \mathrm{~J}=1 \mathrm{~Hz}), 8.35(\mathrm{dd}, 1 \mathrm{H}, \mathrm{J}=8 \mathrm{~Hz}, \mathrm{~J}=1$ $\mathrm{Hz}) .{ }^{13} \mathrm{C} \mathrm{NMR}\left(\mathrm{CDCl}_{3}, 200 \mathrm{MHz}\right) \delta 30.0,44.3,65.6,124.2,128.5$, 129.0, 129.1, 138.0, 140.9, 183.1.IR cm ${ }^{-1}: 1699,1586,1559$.

4c: $\mathrm{mp} .87^{\circ} \mathrm{C} .{ }^{1} \mathrm{H} \mathrm{NMR}\left(\mathrm{CDCl}_{3}, 200 \mathrm{MHz}\right) \delta 3.85$ (s, 3H), 5.80 (bs, $1 \mathrm{H}), 6.95(\mathrm{~d}, 1 \mathrm{H}, \mathrm{J}=2 \mathrm{~Hz}), 7.05(\mathrm{~m}, 2 \mathrm{H}), 7.25(\mathrm{~d}, 1 \mathrm{H}, \mathrm{J}=8.5 \mathrm{~Hz})$, $8.05(\mathrm{~d}, 1 \mathrm{H}, \mathrm{J}=8.5 \mathrm{~Hz}) .{ }^{13} \mathrm{C} \mathrm{NMR}\left(\mathrm{CDCl}_{3}, 200 \mathrm{MHz}\right) \delta 55.2,101.6$, $105.7,118.4,119.6,120.1,123.9,128.9,135.2,148.2,158.3 . \mathrm{IR} \mathrm{cm}^{-1}$ : 3530, 1622, 1595.

4d: $\mathrm{mp} .60^{\circ} \mathrm{C} .{ }^{1} \mathrm{H} \mathrm{NMR}\left(\mathrm{CDCl}_{3}, 200 \mathrm{MHz}\right) \delta 3.95(\mathrm{~s}, 3 \mathrm{H}), 5.35$ (bs, 1H), 7.10-7.25 (m, 3H), $7.45(\mathrm{~d}, 1 \mathrm{H}, \mathrm{J}=2 \mathrm{~Hz}), 7.70(\mathrm{~d}, 1 \mathrm{H}, \mathrm{J}=9 \mathrm{~Hz})$. ${ }^{13} \mathrm{C} \mathrm{NMR}\left(\mathrm{CDCl}_{3}, 200 \mathrm{MHz}\right) \delta 55.3,100.5,104.7,119.5,121.0$, 125.5, 125.8, 128.8, 129.1, 147.0, 157.9. IR cm ${ }^{-1}$ : 3497, 1626, 1591. 4e: mp. $75^{\circ} \mathrm{C} .{ }^{1} \mathrm{H}$ NMR $\left(\mathrm{CDCl}_{3}, 200 \mathrm{MHz}\right) \delta 3.90(\mathrm{~s}, 3 \mathrm{H}), 3.92(\mathrm{~s}$, $3 \mathrm{H}), 3.94$ (s, 3H), 5.00-5.50 (bs, $1 \mathrm{H}), 7.15(\mathrm{~s}, 1 \mathrm{H}), 7.20(\mathrm{~d}, 1 \mathrm{H}, \mathrm{J}=9$ $\mathrm{Hz}), 7.40(\mathrm{~d}, 1 \mathrm{H}, \mathrm{J}=9 \mathrm{~Hz}) .{ }^{13} \mathrm{C} \mathrm{NMR}\left(\mathrm{CDCl}_{3}, 200 \mathrm{MHz}\right) \delta 55.8,60.1$, $61.4,97.2,105.2,115.2,124.5,126.0,129.1,152.1,152.6,152.9$, 162.2. IR $\mathrm{cm}^{-1}: 3497,1629,1590$.

4f: $\mathrm{mp} .70-72^{\circ} \mathrm{C} .{ }^{1} \mathrm{H} \mathrm{NMR}\left(\mathrm{CDCl}_{3}, 200 \mathrm{MHz}\right) \delta 6.05(\mathrm{~s}, 1 \mathrm{H}), 7.30$ $(\mathrm{dd}, 1 \mathrm{H}, \mathrm{J}=8.5 \mathrm{~Hz}, \mathrm{~J}=8.0 \mathrm{~Hz}), 7.55(\mathrm{~d}, 1 \mathrm{H}, \mathrm{J}=9 \mathrm{~Hz}), 7.70(\mathrm{~d}, 1 \mathrm{H}, \mathrm{J}$ $=9 \mathrm{~Hz}), 7.80(\mathrm{dd}, 1 \mathrm{H}, \mathrm{J}=8 \mathrm{~Hz}, \mathrm{~J}=1 \mathrm{~Hz}), 8.20(\mathrm{~d}, 1 \mathrm{H}, \mathrm{J}=8.5 \mathrm{~Hz})$. ${ }^{13} \mathrm{C} \mathrm{NMR}\left(\mathrm{CDCl}_{3}, 200 \mathrm{MHz}\right) \delta 105.2,120.5,122.2,122.6,125.6$, 126.3, 129.4, 130.8, 132.4, 148.2. IR cm ${ }^{-1}: 3406,1616,1583$.

4g: mp. $142^{\circ} \mathrm{C} .{ }^{1} \mathrm{H}$ NMR $\left(\mathrm{CDCl}_{3}, 200 \mathrm{MHz}\right) \delta 3.90(\mathrm{~s}, 3 \mathrm{H}), 5.80$ (bs, $1 \mathrm{H}), 7.05-7.20(\mathrm{dd}, 1 \mathrm{H}, \mathrm{J}=9 \mathrm{~Hz}, \mathrm{~J}=2.5 \mathrm{~Hz}), 7.45(\mathrm{~d}, 1 \mathrm{H}, \mathrm{J}=2.5$ $\mathrm{Hz}), 7.55(\mathrm{~s}, 1 \mathrm{H}), 7.85-7.95(\mathrm{~d}, 1 \mathrm{H}, \mathrm{J}=9 \mathrm{~Hz}) .{ }^{13} \mathrm{C} \mathrm{NMR}\left(\mathrm{CDCl}_{3}, 200\right.$ MHz) $\delta 55.4,101.0,103.7,113.1,120.4,126.0,126.7,128.4,128.7$, 146.9, 158.3. IR cm c $^{-1}: 3441,1585,1497$.

15 Brimble, M. A. ; Brenstrum, T.J. J. Chem. Soc., Perkin Trans. 1, 2001, 1624-1631.

16 Jiang, Y.-Y. ; Li, Q. ; Lu, W. ; Cai, J.-C. Tetrahedron Lett., 2003, 44, 2073-2075.

17 General procedure for the synthesis of 2-bromo-1-naphtols under base free conditions: In a round bottomed flask, a solution of tetralone $2(1 \mathrm{mmol})$ and MPHT $(2 \mathrm{mmol})$ in $\mathrm{CH}_{3} \mathrm{CN}(10 \mathrm{~mL})$ was stirred in an oil bath at $80^{\circ} \mathrm{C}$ for $18 \mathrm{~h}$. The reaction mixture was cooled and treated as above (ref 13).

18 (a) Mosettig, E.; Everette, L. M. J. Org. Chem. 1940, 5, 528-536. (b) Brewster, W. K.; Nichols, D. E.; Watts, V. J.; Riggs, R. M.; Mottola, D.; Mailman, R. B. J. Med. Chem. 1995, 38, 318-327. (c) Hulme, A. H.; Henry, S. S.; Meyers, A. I. J. Org. Chem. 1995, 60, 1265-1270. 